\section{The Albanian Fauna}

The extensive fighting in Albania is in a region rich in natural history interest, particularly ornithology, where Hugh Whistler, Dr. Ticehurst, Prof. P. A. Buxton, W. E. Clyde Todd and Ludwig von Fuehrer have made collections in recent years (Ibis, 1929, 1932,1936 ) and 272 bird forms have been listed. Nesting chaffinches examined from Albania have been found to be Fringilla coelebs balearica and not the typical form, but there is much of British interest in the bird life. Jays are fairly common in the valleys, up to $1,200 \mathrm{ft}$., and they have been seen at 1,500 ft. in the Logra Forest on the Acroceraunian Mountains. Magpies (Corvus cernix sardonius and Corvus monedula soemmerungii) are not so common as formerly reported, and not usually above $2,500 \mathrm{ft}$. Orioles are common. In his expeditions from Valona to the Acroceraunian Range in 1935, Whistler for the first time verified the great black woodpecker occurring in the country (Ibis, April 1936), while birds collected by Ludwig von Fuehrer in 1932 are now in the Carnegie Museum at Pittsburgh. The Spanish sparrow and blackbird are widespread, though local, and there are tree-creepers, marsh-tits, rock-nuthatches, numerous Spanish wheatears, and the robin nesting at 2,500 ft. in the Logra Forests. The imperial eagle nests in open country, the goshawk in the Jinokastro valley, and there are hobbies, peregrines, sea-eagles and harriers; white storks inhabit the ruined towers in summer and a colony of pygmy cormorants nests in the middle of the Lake Terbuf. Colonies of egret nest on the marshes at Durazzo, Valona, etc., along with garganey, pintail, bitterns, purple herons, Kentish plover, pelicans, and yellow-legged herring-gulls, and the adjoining woods have six species of woodpecker, hazel grouse, capercailzie, Cetti's warbler and subalpine warblers. The alpine accentor and alpine chough inhabit the mountains, the thick-billed reedbunting, bearded reedling and penduline tit the plains, the dipper is common at the mountain streams, the crested tit in the fir forests and the redrumped swallow in many districts.

\section{Leeds University Union's Loan}

The University Union, comprising the whole body of students of the University of Leeds, has decided to lend to the Government free of interest the sum of $£ 1,000$. In consequence of the postponement of the construction of the proposed swimming bath and of the extension of the existing gymnasium, the Union found itself with a balance of money which had been set aside for use in connexion with those new developments. In these circumstances the Union Committee felt that this money might appropriately be placed in the hands of the Government until such time as it can be devoted to its original purpose, that is until building work again becomes possible after the War. The University authorities approved of the Committee's proposal and of its wish to forego interest on the loan. The Union has also invested the sum of $£ 400$ in Defence Bonds.
The New "Nomenclator Zoologicus"

IT is satisfactory to be able to report that the publication of the "Nomenclator Zoologicus", an announcement respecting which was made in NATURE of February 25, 1939, p. 326, has now been completed. Moreover, in spite of the inevitable difficulties that have arisen out of the conditions under which the later volumes have been produced, the final one has appeared nearly two months in advance of schedule. The work, which covers the literature from 1758 to the end of 1935 , is contained in four volumes, the last of which includes a supplementary list of addenda and corrigenda. It contains in all about 227,000 entries, including cross-references, though it is probable that these do not represent more than about 190,000 genera or subgenera treated as distinct by present-day systematists. Of these, the Arthropoda represent more than 70 per cent of the whole, the Insecta alone representing 50 per cent.

In the preparation of the work, the editor, Dr. S. A. Neave, Imperial Institute of Entomology, 41 Queen's Gate, London, S.W.7, has had the ungrudging assistance, not only of most of the staff of the British Museum (Natural History), but also of numerous other zoologists both in Great Britain and abroad. The work is published for the proprietors by the Zoological Society of London, which has borne the main cost of compilation. Thanks to grants from outside sources, including the Carnegie Corporation of New York, it was found possible to issue the complete work of more than 3,800 pages to original subscribers at the low price of six guineas; but it has now been found necessary to raise this to ten guineas.

\section{Luigi Luciani}

Prof. Luigi Luciani, the celebrated Italian physiologist, was born at Ascoli Piceno on November 23,1840 . He received his medical education at Bologna and Naples, and qualified at Bologna in 1868. After acting as assistant to Vella in the Institute of Physiology at Bologna he spent nearly two years in the corresponding institute at Leipzig under Ludwig. On his return to Bologna he became lecturer in experimental pathology and also devoted himself to the study of the physiology of respiration. In 1875 he was appointed professor of physiology at Parma, where he remained for five years. In 1880 he succeeded Giannozzi in the corresponding chair at Sienna, and shortly afterwards became professor of comparative physiology at Florence, where he remained from 1880 until 1892. During this period his most important work, namely, that on the cerebellum and fasting, was carried out. Finally, he occupied the chair of physiology at Rome, which he held until his retirement in 1917. His original work consisted mainly of his studies on the physiology of the cardiovascular system, the cerebral cortex and cerebellum muscular movements and. fasting, the last being carried out on Succi, the professional fasting man. $\mathrm{He}$ was also interested in phonetics, psychology, and the history of medicine. His most important publications were those on the functional 
localization of the cerebellum (1885), the physiology of fasting (1889), and human physiology (1898-1903), the latter having been translated into English, German and Spanish. He died on June 23, 1919.

\section{Louis Stromeyer Little}

Мк. Louts Stromeyer Littrue, an eminent surgeon and astronomer, was born in London on November 23, 1840, the third son of Dr. William Little, the orthopædist who gave his name to cerebral diplegia. He was educated at St. Paul's School and at Kiel and Hanover. $\mathrm{He}$ qualified M.R.C.S. in 1862 and the same year became assistant surgeon at the London Hospital, and later was appointed to the National Orthopædic Hospital and St. Mary's Hospital for Women and Children. In 1866, when an epidemic of Asiatic cholera occurred in the East End of London and application was made to the London Hospital for assistance, he took an active and successful part in its treatment by intravenous injection of saline solutions. On the outbreak of the Schleswig-Holstein War in 1864, Little first joined the Prussians, but afterwards joined the Danish forces. In 1869 he went to Shanghai where he soon acquired the best medical practice in the Far East. $\mathrm{He}$ also developed the knowledge of astronomy which he had acquired in London to a remarkable extent, and not only built an observatory at Shanghai, but also established the first telegraphic longitude observed in China by means of telegraphic signals with Nagasaki, 600 miles away on the opposite shore of the Yellow Sea. This achievement gained him the fellowship of the Royal Astronomical Society in 1877. After residence in China for nearly thirty years he returned to England via South Africa, where he was awarded the South African Medal for his services in the Boer War. He died on October 4, 1911.

\section{Prof. Carlo Giacomini}

Prof. Carlo Giacomini, an eminent Italian anatomist and anthropologist, was born at Sale near Alessandria on November 25, 1840. He obtained his medical qualification in 1864 at Turin, where he divided his time between anatomy and clinical medicine until 1880, when he was appointed professor of anatomy and gained a high reputation as a teacher. The classical researches with which he is connected are those on the anatomy and teratology of the brain, his method of preservation of the cerebral convolutions, the anatomy of the negro, and investigations on anomalies of development of the human embryo. He was also co-editor of L'Osservatore. The Museum of Anatomy at Turin owes much to him for its collections. He died at Turin on July 25, 1892.

\section{The Newcomen Society}

ON November 13, at the Iron and Steel Institute, the Newcomen Society held its annual general meeting, and then listened to the reading of two papers. In the report of the Council for the year 1939-40, it was stated that 322 new members have been elected and the membership now stands at 1,512. The majority of the new members are citizens of the United States. Though owing to the stress of war two London meetings were cancelled, a good series of papers were read and many other activities were carried on. The Council sent a chaplet to Handsworth Church on November 15, 1939, to mark the centenary of the death of William Murdoch, and joint action was taken with the Smeatonian Society to place a tablet in the chambers in Gray's Inn occupied by Smeaton during 1783-1793; but the completion of this memorial has had to be deferred. Among the members whose death has been recorded during the year was Mr. L. F. Loree, who is regarded as the founder of the Society in the United States. After the report had been passed, the meeting re-elected Col. C. E. Davies, of New York, for a second year as president. The papers read were respectively by Mr. E. W. Hulme and Dr. H. W. Dickinson, the latter dealing with the work of Henry Cort, the inventor of the puddling process for the manufacture of wrought iron, while Mr. Hulme's paper was entitled "Prehistoric and Primitive Iron Smelting : Part 2, The Crucible Processes of the East". It has been decided owing to the conditions prevailing that no meetings will be held in December and January, but if possible a resumption will be made in February.

\section{Eradication of Bracken}

BRACKEN has become an increasing menace in recent years, and vigorous efforts are being made to find cheap and efficient means for its eradication. Although systematic cutting or crushing can be entirely successful, the process is slow, about eight cuttings at the rate of two a year being required. A more rapid method of destruction is achieved by either broadcasting or spraying with sodium chlorate, but as 2 cwt. per acre is needed the cost (approximately $£ 4$ an acre) is prohibitive. Chlorate, however, is much more toxic when introduced directly into the plant, and Dr. G. H. Bates has devised a mechanical method whereby the chemical can be applied to the cut end of the bracken frond. The chlorate added in this way rapidly kills the aerial portion, and ultimately destroys the underground rhizomes of the plant; only 15-20 lb. of the chemical is required per acre.

The apparatus and method of use are described in Bulletin 14, Rubber and Agriculture Series, published by the British Rubber Publicity Association, 19 Fenchurch Street, London. Bracken crushers or cutting machines which break or bend the stem are not suited to this direct application technique, as unbroken continuity of the vessels is essential for proper penetration of the chlorate; but with hand scythes or machines with reciprocating knives it works well. A small attachment strapped to the worker's belt has been devised for use with a hand scythe. It does not weigh more than $10 \mathrm{lb}$. when filled with solution and needs only be replenished about four times daily. A rubber tube serves as a feed on to a sponge rubber pad, backed by a meta plate which is attached to the scythe blade. The rate of flow can be controlled. A somewhat similar device 